\title{
Effect of Biofertilizers in Combination with Inorganics on Quality Characters of Carrot
}

\author{
P. Roshni ${ }^{1 *}$, Narasimha Murthy ${ }^{2}$, K. Uma Jyothi ${ }^{1}$ and D.R. Salomi Suneetha ${ }^{1}$ \\ ${ }^{1}$ College of Horticulture, Venkataramannagudem, Dr.Y.S.R.HU, A.P., India \\ ${ }^{2}$ Horticultural Research Station, Pandirimamidi, Dr.Y.S.R.HU, A.P., India \\ *Corresponding author
}

\begin{tabular}{l} 
Key wor d s \\
$\begin{array}{l}\text { Carrot, } \\
\text { Biofertilizers, } \\
\text { Inorganics, Quality }\end{array}$ \\
Article Info \\
\hline $\begin{array}{l}\text { Accepted: } \\
17 \text { December } 2018 \\
\text { Available Online: } \\
\text { 10 January } 2019\end{array}$ \\
\hline
\end{tabular}

A B S T R A C T

The investigation was carried out at the Horticultural Research Station, Dr. Y. S. R. Horticultural University, Andhra Pradesh during Rabi 2017-18 to study the effect of bioinoculants and inorganics on quality characters of carrot. Two factors were taken, the first factor being the chemical fertilizers at three levels (100\%, 75\%, 50\% of RDF) and the second factor was the different combinations of five biofertilizers (PSB, KSB, Azospirillum, Azotobacter, VAM).The experimental design adopted was the factorial RBD with 12 treatment combinations. The results revealed that the individual effect of chemical fertilizers at level 100\% RDF (75:60:50 kg/ha) and biofertilizer's level PSB+ KSB+ Azospirillum + Azotobacter + VAM showed a significant difference in quality characters compared to the other levels. The characters viz., total soluble solids $\left(9.50{ }^{\circ} \mathrm{Brix}\right), \beta$ carotene content $(5.29 \mathrm{mg} / 100 \mathrm{~g})$, total sugars $(10.94 \%)$, reducing sugars $(6.23 \%)$, nonreducing sugars $(4.71 \%)$ and total protein content $(866.63 \mathrm{mg} / 100 \mathrm{~g})$ of carrot were recorded the highest with the application of $100 \% \mathrm{RDF}+\mathrm{PSB}+\mathrm{KSB}+$ Azospirillum + Azotobacter+ VAM. The lowest core diameter $(2.11 \mathrm{~cm})$, a favourable character was achieved with the application $50 \% \mathrm{RDF}+\mathrm{PSB}+\mathrm{KSB}+$ Azotobacter. The end of shelf life was treated, at a stage where 50 per cent of the stored roots become unfit for consumption and the maximum shelf life (3 days) was obtained at lower levels of nutrient applications. Hence, varying rate of nutrients application effect the quality attributes significantly. The use of biofertilizers in combination with the chemical fertilizers would yield higher quality produce and also aid in adding steps towards sustainable crop production, by conserving the soil health.

\section{Introduction}

The production and marketing of vegetable crops are undergoing continuous change globally, due to growing demands of consumers for safe and healthy vegetables. Vegetables make up a major portion of the diet in many parts of the world and play a significant role in human nutrition, especially as sources of vitamins $\left(\mathrm{C}, \mathrm{A}, \mathrm{B}_{1}, \mathrm{~B}_{6}, \mathrm{~B}_{9}, \mathrm{E}\right)$, minerals, dietary fibre and phytochemicals (Dias, 2012). Quality can be defined as a degree of excellence, a high standard or value in terms of appearance and nutritional value. 
The general objectives for any growers is to obtain good yield, uniformity of crop and resistance to abiotic-biotic stress whereas, the objectives for consumers are quality, appearance, shelf life, taste and majorly the nutritional value.

Quality in vegetable crops is often more important than yield for consumers therefore, for the growers to survive, cultivars must be accepted by the market and hence forth meet the demands of the consumers (Silva, 2014). Human and environmental health risks are invited by inappropriate vegetable production practices that arise with the judicial application of nutrients to plants without due regard to the pollution on air, soil or water. The application of unsorted, excessive or insufficient dose of nutrients to plants negatively affects the quality attributes of the crop (Dias, 2011).

Consumers are prepared to pay a premium for such produce if their expectations are met and even the processing sector, other industries prefer vegetables with high TSS, sugars ascorbic acid etc for the varied purposes. A sustainable agriculture today makes a sustainable tomorrow. The different combinations of recommended dose of fertilizers along with the biofertilizers would furnish the immediate requirements and also supply the immobile and the fixed forms of the nutrients thereby improve the various quality traits of the crop. The experiment was conducted with the objective to find the effect of biofertilizers, NPK and the interaction effect of biofertilizers and different levels of NPK on quality characters of carrot.

\section{Materials and Methods}

Field experiment was conducted at Horticultural Research Station, Pandirimamidi that comes under high altitude tribal zone of Andhra Pradesh, India which is situated at an altitude of $250 \mathrm{~m}$ above mean sea level with $17^{\circ} 25^{\prime}$ East latitude and $81^{\circ} 45^{\prime}$ North longitudes. The experimental site received an annual rainfall of $1186 \mathrm{~mm}$. The $\mathrm{pH}$ of irrigation water was recorded as 6.0 and EC was $1.66 \mathrm{dSm}^{-1}$. The land used under the experiment was fairly uniform with $\mathrm{pH}$ of 6.5 . The experiment consisted of twelve treatment combinations with three levels of inorganics (100\% RDF $\left(\mathrm{F}_{1}\right)-75: 60: 50 \mathrm{~kg} / \mathrm{ha} ; 75 \% \mathrm{RDF}$ $\left(\mathrm{F}_{2}\right)-56: 45: 37.5 \mathrm{~kg} / \mathrm{ha}$ and $50 \% \operatorname{RDF}\left(\mathrm{F}_{3}\right)-$ 37.5:30:25 $\mathrm{kg} / \mathrm{ha}$ ) and four levels of biofertilizers ( $\mathrm{PSB}+\mathrm{KSB}+$ Azospirillum $\left(\mathrm{B}_{1}\right)$, $\mathrm{PSB}+\mathrm{KSB}+$ Azotobacter $\left(\mathrm{B}_{2}\right), \mathrm{PSB}+\mathrm{KSB}+$ Vesicular Arbuscular Michorrhiza $\left(\mathrm{B}_{3}\right), \mathrm{PSB}+$ $\mathrm{KSB}+$ Azospirillum + Azotobacter + VAM $\left.\left(\mathrm{B}_{4}\right)\right)$. The factorial randomized block design was adopted with three replications. The experimental field was thoroughly ploughed to a depth of $30 \mathrm{~cm}$ and harrowed twice. The field was laid at a gross plot size of $2.2 \mathrm{~m} \mathrm{X}$ $1.8 \mathrm{~m}$ and net plot size of $2 \mathrm{~m} \mathrm{X} 1.5 \mathrm{~m}$. The biofertilizers (PSB, KSB, Azospirillum, Azotobacter, VAM) were applied to soil, by adding them to well decomposed FYM as per different treatments at the rate of $5 \mathrm{~kg} / \mathrm{ha}$. The field was irrigated and let for the beneficial microorganisms to grow. Carrot seed cv. Pusa Rudhira was sown in ridge and furrow system at a depth of $1 \mathrm{~cm}$. Standard cultural and management practices were adopted. Observations were recorded on various quality traits viz., total soluble solids, $\beta$-carotene content, total sugars, reducing sugars, nonreducing sugars and total protein content of carrot. The end of shelf life was treated, at a stage where 50 per cent of the stored roots become unfit for consumption. The data collected was subjected to analysis of variance (ANOVA). The test of significance (t-test) and critical difference was calculated at $0.05 \%$ probability.

\section{Results and Discussion}

The results obtained highlight the importance of the significant variation within the various levels of inorganics and biofertilizers, singly 
and also in combinations. The TSS of carrot recorded highest $\left(8.84{ }^{\circ} \mathrm{B}\right)$ in the plants applied with $100 \%$ RDF $\left(\mathrm{F}_{1}\right)$ followed by $75 \%$ RDF $\left(\mathrm{F}_{2}\right)$ and $50 \% \mathrm{RDF}\left(\mathrm{F}_{3}\right)$ with $8.50{ }^{\circ} \mathrm{B}$ and $7.99{ }^{\circ} \mathrm{B}$ respectively. Biofertilizers $\mathrm{PSB}+$ $\mathrm{KSB}+$ Azospirillum+ Azotobacter+ VAM $\left(\mathrm{B}_{4}\right)$ recorded the highest $\left(8.94{ }^{\circ} \mathrm{B}\right) \mathrm{TSS}$, followed by $\mathrm{PSB}+\mathrm{KSB}+$ Azotobacter $\left(\mathrm{B}_{2}\right)$ with $8.42{ }^{\circ} \mathrm{B}$ and $\mathrm{PSB}+\mathrm{KSB}+\mathrm{VAM}\left(\mathrm{B}_{3}\right)$ with $8.32{ }^{\circ} \mathrm{B}$ were found to be on par with each other.

The crop applied with $100 \% \mathrm{RDF}+\mathrm{PSB}+$ $\mathrm{KSB}+$ Azospirillum + Azotobacter +VAM $\left(\mathrm{F}_{1} \mathrm{~B}_{4}\right)$ combination reported the maximum interaction effect and recorded highest TSS of $9.50{ }^{\circ} \mathrm{B}$ followed by $100 \% \mathrm{RDF}+\mathrm{PSB}+$ $\mathrm{KSB}+$ Azotobacter $\left(\mathrm{F}_{1} \mathrm{~B}_{2}\right)$ with $8.80{ }^{\circ} \mathrm{B}$.

The increasing $\mathrm{K}$ fertilizer played a key role in increasing the root TSS value. The higher dosage of nutrients provided to the crop hastens the metabolic activity in the shoot and the accumulation of photosynthates there by accumulation of various forms of carbohydrates i.e. sugars (predominantly sucrose). The findings are in agreement with Lyngdoh (2001) in carrot. It was suggested that, this could be due to the improvement of soil structure and improved nutrient and moisture status of the soil in favour of plant growth due to application of bio fertilizers.

Higher core diameter is considered as an unfavourable character. It was observed that the different levels of chemical fertilizers, biofertilizers and also the interaction of both the factors at various levels had no significant effect on core diameter of the roots. However, at lower levels of chemical fertilizers and biofertilizers, the lowest root diameter was recorded, which ultimately resulted in a lower core diameter.

The nutrition plays an important role for $\beta$ carotene content and protein accumulation in the roots. The $\beta$-carotene and protein content increased with increasing levels of chemical fertilizers and recorded the highest of 5.06 $\mathrm{mg} / 100 \mathrm{~g}$ and $823.47 \mathrm{mg} / 100 \mathrm{~g}$ respectively with the treatment of $100 \%$ RDF $\left(\mathrm{F}_{1}\right)$, followed by $75 \% \operatorname{RDF}\left(\mathrm{F}_{2}\right)$ and $50 \% \operatorname{RDF}\left(\mathrm{F}_{3}\right)$ (Table 1). Similarly, biofertilizers PSB+ $\mathrm{KSB}+$ Azospirillum + Azotobacter + VAM $\left(\mathrm{B}_{4}\right)$ recorded the highest $\beta$-carotene content of $5.05 \mathrm{mg} / 100 \mathrm{~g}$ and protein $828.40 \mathrm{mg} / 100 \mathrm{~g}$ followed by the application of $\mathrm{PSB}+\mathrm{KSB}+$ Azotobacter $\left(\mathrm{B}_{2}\right)$ with $4.68 \mathrm{mg} / 100 \mathrm{~g}$ and $808.02 \mathrm{mg} / 100 \mathrm{~g}$ respectively. The lowest values in trems of $\beta$-carotene and protein content were recorded with $\mathrm{PSB}+\mathrm{KSB}+$ Azospirillum $\left(\mathrm{B}_{1}\right)$ application (Table 1).

It was observed that within the interaction effects $100 \% \quad \mathrm{RDF}+\mathrm{PSB}+\mathrm{KSB}+$ Azospirillum + Azotobacter+ VAM $\left(\mathrm{F}_{1} \mathrm{~B}_{4}\right)$ recorded the highest $\beta$-carotene and protein contents $5.29 \mathrm{mg} / 100 \mathrm{~g}$ and $866.68 \mathrm{mg} / 100 \mathrm{~g}$ respectively, followed by $100 \% \mathrm{RDF}+\mathrm{PSB}+$ $\mathrm{KSB}+$ Azotobacter $\left(\mathrm{F}_{1} \mathrm{~B}_{2}\right)$ while the lowest values were recorded in the combination of $50 \% \mathrm{RDF}+\mathrm{PSB}+\mathrm{KSB}+$ Azospirillum $\left(\mathrm{F}_{3} \mathrm{~B}_{1}\right)$ in both the parameters (Table 2).

The higher photosynthates accumulation and metabolism in the plant coupled with rapid cell division might be the reason for the highest dose of chemical fertilizers showing relative effect on the biosynthesis of antioxidant compounds, pigments in the plant.

This would be due to specific soil nutrients which might have been more readily available for shoot absorption, as a result of mineral and biofertilizers integration, which activated specific enzymes for the synthesis of carotene in carrot. The results obtained were in accordance with Sanwal et al., (2006) in broccoli and Vithwel and Kanaujia (2013) in carrot. Nitrogen is a fundamental component of amino acids, which are the molecular building blocks of protein. 
Table.1 Quality characters as effected by the different chemical fertilizers and biofertilizers

\begin{tabular}{|c|c|c|c|c|c|c|c|c|}
\hline Treatments & $\begin{array}{c}\text { Total } \\
\text { soluble } \\
\text { solids } \\
\left({ }^{\circ} \text { Brix) }\right.\end{array}$ & $\begin{array}{c}\text { Core } \\
\text { diameter } \\
\text { (cm) }\end{array}$ & $\begin{array}{l}\beta \text {-Carotene } \\
(\mathrm{mg} / 100 \mathrm{~g})\end{array}$ & $\begin{array}{c}\text { Total } \\
\text { protein } \\
(\mathrm{mg} / 100 \\
\mathrm{g})\end{array}$ & $\begin{array}{c}\text { Total } \\
\text { sugars } \\
(\%)\end{array}$ & $\begin{array}{c}\text { Reducing } \\
\text { sugars } \\
(\%)\end{array}$ & $\begin{array}{c}\text { Non- } \\
\text { reducing } \\
\text { sugars } \\
(\%)\end{array}$ & $\begin{array}{l}\text { Shelf life } \\
\text { (days) }\end{array}$ \\
\hline \multicolumn{9}{|l|}{ Chemical fertilizers } \\
\hline $100 \% \operatorname{RDF}\left(\mathrm{F}_{1}\right)$ & 8.84 & 2.57 & 5.06 & 823.47 & 18.16 & 13.50 & 11.13 & 2.66 \\
\hline $75 \%$ RDF $\left(\mathrm{F}_{2}\right)$ & 8.50 & 2.50 & 4.49 & 803.55 & 17.09 & 13.23 & 10.44 & 2.58 \\
\hline $50 \% \operatorname{RDF}\left(\mathrm{F}_{3}\right)$ & 7.99 & 2.36 & 4.21 & 701.71 & 16.32 & 12.18 & 10.20 & 2.58 \\
\hline C.D. at $5 \%$ & 0.09 & $\mathrm{~N} / \mathrm{S}$ & 0.17 & 9.69 & 0.55 & 0.74 & 1.05 & $\mathrm{~N} / \mathrm{S}$ \\
\hline $\mathrm{SE}(\mathrm{m}) \pm$ & 0.03 & - & 0.05 & 3.28 & 0.18 & 0.25 & 0.35 & - \\
\hline \multicolumn{9}{|l|}{ Biofertilizers } \\
\hline PSB+ KSB+ Azospirillum $\left(\mathrm{B}_{1}\right)$ & 8.09 & 2.42 & 4.16 & 704.02 & 15.71 & 12.15 & 9.23 & 2.55 \\
\hline $\mathrm{PSB}+\mathrm{KSB}+$ Azotobacter $\left(\mathrm{B}_{2}\right)$ & 8.42 & 2.39 & 4.68 & 808.02 & 17.59 & 13.16 & 11.22 & 2.66 \\
\hline $\mathrm{PSB}+\mathrm{KSB}+\mathrm{VAM}\left(\mathrm{B}_{3}\right)$ & 8.32 & 2.54 & 4.45 & 764.53 & 16.96 & 12.66 & 9.87 & 2.77 \\
\hline $\begin{array}{l}\text { PSB+KSB+Azospirillum }+ \text { Azotobacter } \\
+ \text { VAM }\left(\mathrm{B}_{4}\right)\end{array}$ & 8.94 & 2.57 & 5.05 & 828.40 & 18.50 & 13.91 & 12.04 & 2.44 \\
\hline C.D. at $5 \%$ & 0.11 & $\mathrm{~N} / \mathrm{S}$ & 0.19 & 11.19 & 0.63 & 0.85 & 1.21 & $\mathrm{~N} / \mathrm{S}$ \\
\hline $\mathrm{SE}(\mathbf{m}) \pm$ & 0.03 & - & 0.06 & 3.79 & 0.21 & 0.29 & 0.41 & - \\
\hline
\end{tabular}

NOTE: The values for the total, reducing and non-reducing sugars are transformed values, as for percentages angular transformation is followed. 
Table.2 Quality characters as affected by different combinations of chemical fertilizers and biofertilizers

\begin{tabular}{|c|c|c|c|c|c|c|c|c|}
\hline Treatment combinations & $\begin{array}{c}\text { Total } \\
\text { soluble } \\
\text { solids } \\
\left({ }^{\circ} \text { Brix) }\right.\end{array}$ & $\begin{array}{c}\text { Core } \\
\text { diameter } \\
(\mathrm{cm})\end{array}$ & $\begin{array}{c}\beta- \\
\text { Carotene } \\
(\mathrm{mg} / 100 \\
\mathrm{g})\end{array}$ & $\begin{array}{c}\text { Total } \\
\text { protein } \\
\text { (mg/100 } \\
\text { g) }\end{array}$ & $\begin{array}{c}\text { Total } \\
\text { sugars } \\
(\%)\end{array}$ & $\begin{array}{c}\text { Reducing } \\
\text { sugars }(\%)\end{array}$ & $\begin{array}{l}\text { Non- } \\
\text { reducing } \\
\text { sugars } \\
(\%)\end{array}$ & $\begin{array}{l}\text { Shelf life } \\
\text { (days) }\end{array}$ \\
\hline $100 \% \mathrm{RDF}+\mathrm{PSB}+\mathrm{KSB}+$ Azospirillum $\quad\left(\mathrm{F}_{1} \mathrm{~B}_{1}\right)$ & 8.35 & 2.35 & 4.66 & 750.07 & $\begin{array}{c}8.53 \\
(16.97)\end{array}$ & $\begin{array}{c}4.8 \\
(12.60)\end{array}$ & $\begin{array}{l}3.73 \\
(9.91)\end{array}$ & 3.0 \\
\hline $100 \% \mathrm{RDF}+\mathrm{PSB}+\mathrm{KSB}+$ Azotobacter $\quad\left(\mathrm{F}_{1} \mathrm{~B}_{2}\right)$ & 8.80 & 2.64 & 5.18 & 852.88 & $\begin{array}{c}10.02 \\
(18.43)\end{array}$ & $\begin{array}{c}5.81 \\
(13.94)\end{array}$ & $\begin{array}{c}4.21 \\
(11.46)\end{array}$ & 2.66 \\
\hline $100 \% \mathrm{RDF}+\mathrm{PSB}+\mathrm{KSB}+\mathrm{VAM} \quad\left(\mathrm{F}_{1} \mathrm{~B}_{3}\right)$ & 8.72 & 2.62 & 5.12 & 824.23 & $\begin{array}{c}9.51 \\
(17.95)\end{array}$ & $\begin{array}{c}5.32 \\
(13.03)\end{array}$ & $\begin{array}{c}4.39 \\
(10.23)\end{array}$ & 2.66 \\
\hline $\begin{array}{c}100 \% \mathrm{RDF}+\mathrm{PSB}+\mathrm{KSB}+\text { Azospirillum }+ \text { Azotobacter }+ \\
\text { VAM } \\
\left(\mathrm{F}_{1} \mathrm{~B}_{4}\right)\end{array}$ & 9.50 & 2.69 & 5.29 & 866.68 & $\begin{array}{c}10.94 \\
(19.29)\end{array}$ & $\begin{array}{c}6.23 \\
(14.44)\end{array}$ & $\begin{array}{c}4.71 \\
(12.91)\end{array}$ & 2.33 \\
\hline $75 \%$ RDF+ PSB+ KSB+ Azospirillum $\quad\left(\mathbf{F}_{2} \mathbf{B}_{1}\right)$ & 8.25 & 2.57 & 4.11 & 766.27 & $\begin{array}{c}7.25 \\
(15.61)\end{array}$ & $\begin{array}{c}4.86 \\
(12.72)\end{array}$ & $\begin{array}{c}2.54 \\
(9.04)\end{array}$ & 2.33 \\
\hline $75 \%$ RDF+ PSB+ KSB+ Azotobacter $\quad\left(\mathbf{F}_{2} \mathbf{B}_{2}\right)$ & 8.54 & 2.43 & 4.56 & 805.06 & $\begin{array}{c}9.03 \\
(17.46)\end{array}$ & $\begin{array}{c}5.32 \\
(13.29)\end{array}$ & $\begin{array}{c}3.71 \\
(10.81)\end{array}$ & 3.00 \\
\hline $75 \% \mathrm{RDF}+\mathrm{PSB}+\mathrm{KSB}+\mathrm{VAM} \quad\left(\mathrm{F}_{2} \mathbf{B}_{3}\right)$ & 8.46 & 2.33 & 4.11 & 795.87 & $\begin{array}{c}8.61 \\
(17.05)\end{array}$ & $\begin{array}{c}5.04 \\
(12.96)\end{array}$ & $\begin{array}{c}3.56 \\
(10.45)\end{array}$ & 2.66 \\
\hline $\begin{array}{l}\text { 75\% RDF+PSB+KSB+Azospirillum }+ \text { Azotobacter }+ \\
\text { VAM } \\
\left(\mathrm{F}_{2} \mathbf{B}_{4}\right)\end{array}$ & 8.76 & 2.11 & 5.17 & 847.01 & $\begin{array}{c}9.81 \\
(18.24)\end{array}$ & $\begin{array}{c}5.81 \\
(13.94)\end{array}$ & $\begin{array}{c}3.99 \\
(11.47)\end{array}$ & 2.33 \\
\hline $50 \%$ RDF+ PSB+ KSB+ Azospirillum $\quad\left(\mathbf{F}_{3} \mathbf{B}_{1}\right)$ & 7.69 & 2.41 & 3.71 & 595.73 & $\begin{array}{c}6.33 \\
(14.56)\end{array}$ & $\begin{array}{c}3.78 \\
(11.13)\end{array}$ & $\begin{array}{c}2.38 \\
(8.75)\end{array}$ & 2.33 \\
\hline $50 \%$ RDF + PSB+ KSB+ Azotobacter $\quad\left(\mathbf{F}_{3} \mathbf{B}_{2}\right)$ & 7.93 & 2.58 & 4.30 & 766.13 & $\begin{array}{c}8.45 \\
(16.87)\end{array}$ & $\begin{array}{c}4.51 \\
(12.25)\end{array}$ & $\begin{array}{c}3.94 \\
(11.38)\end{array}$ & 2.33 \\
\hline $50 \%$ RDF + PSB+ KSB+ VAM & 7.80 & 2.41 & 4.13 & 673.48 & $\begin{array}{c}7.51 \\
(15.87)\end{array}$ & $\begin{array}{c}4.36 \\
(11.99)\end{array}$ & $\begin{array}{l}3.15 \\
(8.93)\end{array}$ & 3.00 \\
\hline $\begin{array}{c}50 \% \mathrm{RDF}+\mathrm{PSB}+\mathrm{KSB}+\text { Azospirillum }+ \text { Azotobacter }+ \\
\text { VAM } \\
\left(\mathbf{F}_{3} \mathbf{B}_{4}\right)\end{array}$ & 8.56 & 2.58 & 4.70 & 771.50 & $\begin{array}{c}9.53 \\
(17.97)\end{array}$ & $\begin{array}{c}5.35 \\
(13.36)\end{array}$ & $\begin{array}{c}4.18 \\
(11.73)\end{array}$ & 2.66 \\
\hline C.D. at $5 \%$ & 0.19 & $\mathrm{~N} / \mathrm{S}$ & 0.34 & 19.38 & 0.92 & 1.31 & 1.91 & $\mathrm{~N} / \mathrm{S}$ \\
\hline $\mathrm{SE}(\mathrm{m}) \pm$ & 0.06 & - & 0.11 & 6.56 & 0.37 & 0.50 & 0.71 & - \\
\hline
\end{tabular}

NOTE: The values in the brackets are transformed values, as for percentages angular transformation is followed 
Therefore, increase in nitrogen based inputs, through the increasing levels of inorganics and biofertilizers would have triggered the protein accumulation. The use of biofertilizers improved the nitrogen availability for the plants by binding the atmospheric nitrogen and thus, improving the bioactive molecules in the roots.

The results obtained were in line with Solanki et al., (2010) in brinjal and with Singh et al., (2014) in broccoli who reported that the combination of biofertilizers along with chemical fertilizers recorded a high protein and lipid profile along with phosphate and sulphate content of broccoli curds.

The sugar's content increased linearly with the increasing fertilizer levels. The highest total sugars (18.16\%), reducing sugars $(13.50 \%)$ and non-reducing sugars $(11.13 \%)$ with $100 \% \mathrm{RDF}\left(\mathrm{F}_{1}\right)$ followed by $75 \% \mathrm{RDF}$ $\left(\mathrm{F}_{2}\right)$ and $50 \% \operatorname{RDF}\left(\mathrm{F}_{3}\right)$ (Table 1).

Among the various biofertilizers the application of $\mathrm{PSB}+\mathrm{KSB}+$ Azospirillum + Azotobacter+ VAM $\left(\mathrm{B}_{4}\right)$ recorded the highest total sugar (18.50\%), reducing sugar $(14.44 \%)$ and non- reducing sugars $(12.04 \%)$ followed by $\mathrm{PSB}+\mathrm{KSB}+$ Azotobacter $\left(\mathrm{B}_{2}\right)$ and $\mathrm{PSB}+\mathrm{KSB}+\mathrm{VAM}\left(\mathrm{B}_{3}\right)$ (Table 1). Within the total sugars $\mathrm{PSB}+\mathrm{KSB}+$ Azotobacter $\left(\mathrm{B}_{2}\right)$ recorded $17.59 \%$ and was on par with PSB+ KSB+ VAM $\left(\mathrm{B}_{3}\right)$ with $16.96 \%$. The results with regard to non-reducing sugars showed, that the treatment of biofertilizers PSB+ KSB+ Azospirillum + Azotobacter+ VAM $\left(\mathrm{B}_{4}\right)$ was on par with $\mathrm{PSB}+\mathrm{KSB}+$ Azotobacter $\left(\mathrm{B}_{2}\right)$ with $11.22 \%$. The lowest total sugars $(15.71 \%)$, reducing sugar $(11.13 \%)$ and non-reducing sugars $(9.23 \%)$ were recorded with the treatment of $\mathrm{PSB}+$ $\mathrm{KSB}+$ Azospirillum $\left(\mathrm{B}_{1}\right)$. The treatment combinations at various levels of chemical fertilizers and biofertilizers recorded the highest values of total sugars (19.29\%), reducing sugar (14.44\%), non-reducing sugars $(12.91 \%)$ in the plants applied with $100 \%$ $\mathrm{RDF}+\mathrm{PSB}+\mathrm{KSB}+$ Azospirillum+ Azotobacter+ VAM $\left(\mathrm{F}_{1} \mathrm{~B}_{4}\right)$ followed by $100 \%$ $\mathrm{RDF}+\mathrm{PSB}+\mathrm{KSB}+$ Azotobacter $\left(\mathrm{F}_{1} \mathrm{~B}_{2}\right)$ while, the lowest values were recorded with combination of $50 \% \mathrm{RDF}+\mathrm{PSB}+\mathrm{KSB}+$ Azospirillum $\left(\mathrm{F}_{3} \mathrm{~B}_{1}\right)$ (Table 2$)$.

Total sugars are the sum of reducing and nonreducing sugars, a similar trend of response was observed to be followed as in the case all the sugars. The nutrients applied increased the shoot growth and photosynthetic accumulation this might have increased the sugar content in the roots as a fact that fertilizers play a key role in effective development of the plants, as each mineral nutrient has a specific role in running a dynamic system in the plants which yield various quality and quantity related characters in the plants' internal processes. Solanki et al., (2010) also obtained similar results with regard to sugars in brinjal crop.

The presence of PSB, KSB and VAM would have increased the availability of nutrients by forming symbiotic associations with the plants and increasing the surface of absorbtion along with mobilising the nutrients. Abdelaal and Sahar (2015) also obtained similar results with regard to the application of biofertilizers which improves the efficiency of the nutrient uptake and aids in the storage of sugars after photosynthesis in sugar beet.

The different levels of chemical fertilizers, biofertilizers and the interaction had no significant influence on the shelf life of the carrot roots. The roots were found to lose their edible quality when kept under room temperature within an average of 2-3 days.

The quality of vegetables deteriorates gradually during storage in response to endogenous factors and environmental 
conditions. Processes such as transpiration, respiration, activation of growth and attack by pathogens lead not only to quantitative losses but quality losses, which can destroy the marketability of the product (Sable and Bhamare, 2007).

With the results from the present experiment it can be concluded that the best quality carrots can be obtained with the application of $100 \%$ RDF+ PSB+ KSB+ Azospirillum + Azotobacter+ VAM. As, the complete dose of fertilizers would add in the crops the immediate source of nutrition for the metabolisms to show appropriate growth and the biofertilizers would supply the required nutrients throughout the season in a sustainable manner and available form by maintaining the soil health.

\section{References}

Abdelaal, K. A. A. and Sahar, F. T. 2015. Response of sugar beet plant (Beta vulgaris L.) to mineral nitrogen fertilization and biofertilizers. International journal Current Microbiology Applied Science. 4(9): 677-88.

Dias, J.S. 2012. Major classes of phytonutriceuticals in vegetables and health benefits: A review. Journal of Nutritional Therapeutics, 1, 31-62.

Dias, J.S. and Ryder, E.J. 2011. World Vegetable Indus- try: Production, breeding, trends. Horticultural Reviews, 38, 299-356.
Lyngdoh, G. B. S. 2001. Response of carrot to different levels of nitrogen, phosphorus and potassium. Horticultural Journal. 14 (2):163-69.

Sable, P. B. and Bhamare, V. K. 2007. Effect of biofertilizers (Azotobacter and Azospirillum) alone and in combination with reduced levels of nitrogen on quality of cauliflower cv. Snowball - 16.The Asian Journal of Horticulture. 2 (1): 215-17.

Sanwal, S. K. Laxminarayana, K. Yadav, D. S. Rai, N. and Yadav, R. K. 2006. Growth, yield, and dietary antioxidants of broccoli. Periodica Polytechnica Ser. Chem. Eng. 36(1): 25-41.

Silva J. C. 2014. Guiding strategies for breeding vegetable cultivars. Agricultural Sciences. 5, 9-32.

Singh, S. Maji, and Kumar. 2014. Effect of biofertilizers on yield and biomolecules of anti-cancerous vegetable broccoli. International Journal of Bioresource and Stress Management. 5(2): 256- 62.

Solanki, M. P. Patel, B. N. Tandel, Y. N. and Patel, N. B. 2010. Growth, yield and quality of brinjal as affected by use of bio-fertilizers. The Asian Journal of Horticulture. 5 (2): 403- 06.

Vithwel and Kanaujia, S. P. 2013. Integrated nutrient management on productivity of carrot and fertility of soil. SAARC Journal of Agriculture. 11(2): 173- 81.

\section{How to cite this article:}

Roshni, P., Narasimha Murthy, K. Uma Jyothi and Salomi Suneetha, D.R. 2019. Effect of Biofertilizers in Combination with Inorganics on Quality Characters of Carrot. Int.J.Curr.Microbiol.App.Sci. 8(01): 2698-2704. doi: https://doi.org/10.20546/ijcmas.2019.801.284 